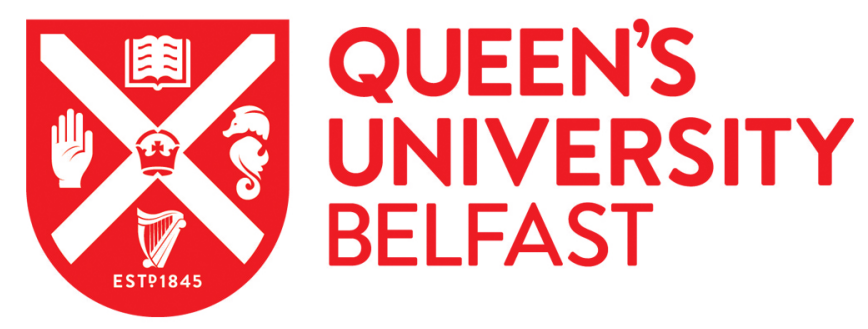

\title{
Development of Antibodies and Immunoassays for Monitoring of Nitrofuran Antibiotics in the Food Chain
}

Cooper, K. M., Fodey, T. L., Campbell, K., \& Elliott, C. T. (2017). Development of Antibodies and Immunoassays for Monitoring of Nitrofuran Antibiotics in the Food Chain. Current Organic Chemistry, 21(26), 2675-2689. https://doi.org/10.2174/1385272821666170427160210

\section{Published in:}

Current Organic Chemistry

\section{Document Version:}

Peer reviewed version

Queen's University Belfast - Research Portal:

Link to publication record in Queen's University Belfast Research Portal

\section{Publisher rights}

(C) 2017 Bentham Science Publishers. This work is made available online in accordance with the publisher's policies. Please refer to any applicable terms of use of the publisher.

\section{General rights}

Copyright for the publications made accessible via the Queen's University Belfast Research Portal is retained by the author(s) and / or other copyright owners and it is a condition of accessing these publications that users recognise and abide by the legal requirements associated with these rights.

Take down policy

The Research Portal is Queen's institutional repository that provides access to Queen's research output. Every effort has been made to ensure that content in the Research Portal does not infringe any person's rights, or applicable UK laws. If you discover content in the Research Portal that you believe breaches copyright or violates any law, please contact openaccess@qub.ac.uk. 


\title{
The published manuscript is available at EurekaSelect via \\ http://www.eurekaselect.com/openurl/content.php?genre=article\&doi=10.2174/138527 2821666170427160210
}

Current Organic Chemistry (2017) Volume 21

\section{Development of Antibodies and Immunoassays for Monitoring of Nitrofuran Antibiotics in the Food Chain}

\author{
Kevin M. Cooper ${ }^{\mathrm{a} *}$, Terry L. Fodey ${ }^{\mathrm{b}}$, Katrina Campbell ${ }^{\mathrm{a}}$, Christopher T. Elliott ${ }^{\mathrm{a}}$ \\ ${ }^{a}$ Institute for Global Food Security, Queen's University Belfast, Belfast, United Kingdom; ${ }^{b}$ Veterinary Sciences \\ Division, Agri-Food and Biosciences Institute, Belfast, United Kingdom
}

\begin{abstract}
Nitrofurans are a broad group of drugs once widely used for treatment of microbial and protozoal infections in many livestock species. However, as concerns grew globally with regard to the potentially carcinogenic and mutagenic effects of their residues in foods, they have been banned from use in many parts of the world. In order to monitor compliance to these bans it is essential to have fitfor-purpose testing methods. Immunoassays are the screening tool of choice for many testing laboratories due to their relative low cost, ease of use and high sensitivity. As is the case with all immunoassays, the most important reagents required are high quality, high affinity antibodies that exhibit the required sensitivity and specificity. Generating such antibodies for the nitrofuran family of compounds has required a great deal of effort in the design of immunogens, as the compounds, due to size, are not capable of eliciting an immune response in hosts and are not easily conjugated to carrier proteins. This article reviews the range of strategies used to successfully generate suitable antibodies to a wide range of these drugs and their metabolites. In addition, the platform technologies for nitrofuran detection have moved from simple enzyme-linked immunosorbent assay (ELISA)-based procedures to more sophisticated multiplexing systems which can undertake faster and broader spectrum testing for the parent drugs and their metabolites. Reviews of the technologies used for immunochemical detection of the nitrofurans and of commercially available test kits are also presented.
\end{abstract}

Keywords: Nitrofuran antibiotics, AOZ, antibodies, immunoassays, food safety, derivatisation, hapten, immunogen.

*Address correspondence to this author at Institute for Global Food Security, David Keir Building, 18-30 Malone Road, Queen's University Belfast, Belfast BT9 5BN, United Kingdom; Tel: +44 2890976562; Fax: +44 2890976513; E-mail: k.cooper@qub.ac.uk

\section{INTRODUCTION}

The nitrofurans are a class of antibiotic and antiprotozoal drugs whose defining structure is a furan ring with a nitro group. Whilst popularly prescribed for clinical treatment of diarrhoea, enteritis and urinary tract infections, during the 1990s they were prohibited within the European Union (EU), and subsequently in several jurisdictions, for use in food-producing animals due to the potentially carcinogenic and mutagenic effects of their residues in food $[1,2]$. They were used previously in livestock production for prevention and treatment of gastrointestinal infections and as growth promoters. Current evidence of the health risks posed by nitrofuran residues in our food has been thoroughly assessed in a recent Scientific Opinion published by the European Food Safety Authority [3]. EU Member States are required to test for the presence of nitrofurans in foodstuffs as part of their National Residues Monitoring Schemes and $3^{\text {rd }}$ countries exporting relevant foods to the EU are 
required to implement analogous control systems. Nitrofuran residue analytical methods used within the EU are required to be sufficiently sensitive to meet the European Commission's Minimum Required Performance Limit (MRPL) of $1 \mu \mathrm{g} / \mathrm{kg}$ which is also now applied as a Reference Point for Action, above which enforcement action must be taken by relevant authorities when violative residues are detected [2].

Nitrofurans are metabolized rapidly in vivo, however, persistent protein-bound metabolites are formed which can be released by acid hydrolysis and used as marker residues for monitoring the abuse of these drugs in the food chain [4]. The major nitrofuran drugs are furazolidone (FZD), furaltadone (FTD), nitrofurantoin (NFT), nitrofurazone (NFZ) and nifursol (NFS), and their marker residues are 3-amino-2-oxazolidinone (AOZ), 3amino-5-morpholinomethyl-2-oxazolidone (AMOZ), 1-aminohydantoin (AHD), semicarbazide (SEM) and 3,5dinitrosalicyclic acid hydrazide (DNSH), respectively (Fig. 1). Improved liquid chromatography-tandem mass spectrometry (LC-MS/MS) analytical methods developed under the EU-funded research project FoodBRAND [4] were instrumental in uncovering widespread abuse of nitrofurans in various worldwide food industries during 2001-02, primarily the aquaculture and poultry industries of SE Asia and S America. The first report of a nitrofuran residue in the food chain recorded in the European Commission's Rapid Alert System for Food and Feed (RASFF; http://ec.europa.eu/food/safety/rasff/) was in February 2002 in eels imported from China. From 2002 to 2015 there were 826 rapid alerts for nitrofurans in a wide range of products from various countries. Of the alerts which specified a particular nitrofuran metabolite residue, 53\% detected SEM, 35\% AOZ, $11 \%$ AMOZ and 1\% AHD. The initial burst of activity in 2002-03 led to 188 rapid alerts per year; the following six years saw an average of 57 alerts per year, whilst the six years from 2010 to 2015 have seen only 19 alerts per year. While it can be argued that the RASFF is not a measure of the prevalence of a particular food safety issue, but rather an indication of which issues competent authorities in Europe are focusing their testing upon, these figures illustrate that nitrofuran residues in the food chain are an ongoing concern. Indeed, there were 39 rapid alerts as recently as 2014 and the continued illicit use of these antibiotics in global food production is evidenced by the significant number of commercially available nitrofuran immunoassay test kits currently on the market.

To complement the HPLC and LC-MS/MS analytical methods already in place, partners in FoodBRAND led the way in developing immunoassay-based screening tests for nitrofuran residues, the first being directed towards AOZ in prawns in 2004 [5, 6]. This led to the situation, highlighted by Points et al. [2], where many laboratories use LC-MS/MS for both high-throughput screening and confirmatory analysis of nitrofurans, since by the time immunoassays were developed for nitrofurans, many laboratories had already invested in LCMS/MS equipment and validated their methods. Furthermore, the range of available nitrofuran immunoassays was incomplete for several years at a time when the "Nitrofuran Crisis" of the early 2000s required screening of the four major nitrofuran residues. Despite this initial prominence of analysis by LC-MS/MS, the demand for rapid and inexpensive screening of nitrofuran residues by immunoassay has grown. Primary food producers and laboratories without access to expensive LC-MS/MS facilities require robust screening tests to ensure that harmful nitrofuran drugs, still widely available online and in use in many countries, are prevented from entering the food chain. This article comprehensively reviews the scientific literature to illustrate the progress made in the design and development of haptens, immunogen conjugates and antibodies to the nitrofurans, their incorporation into various immunoassay formats and technology platforms, and their commercialization as screening test kits to enhance food safety.

\section{NITROFURAN HAPTENS AND CONJUGATES}

Antibodies have been produced to bind the metabolites (Fig. 1), or derivatives of the metabolites, of the five major nitrofuran drugs: AOZ [5, 7-10], SEM [11-15], AMOZ [16-20], AHD [21-25] and DNSH [26]. The majority of publications focus on analysis of food products of animal origin in which these metabolites are the target analytes. Approximately one tenth of reports describe production of antibodies for detection of the parent nitrofuran drugs [27-32] in animal feed or water, the conventional routes of administration to livestock.

\subsection{AOZ Haptens}

The first reported production of an antibody to a nitrofuran analogue was in 2004 by Cooper et al. [5] who produced polyclonal antisera to a derivative of AOZ in rabbits. Difficulty in directly conjugating AOZ to a carrier protein via the amine group of the hapten in order to confer immunogenicity was resolved by using the same functional group to prepare a carboxyphenyl derivative (3-CPAOZ) by refluxing with 3- 
carboxybenzaldehyde (3-CBA) in pyridine (Fig. 2). While LC-MS analysis indicated that 99\% of the 3-CBA had been used in the derivatisation process, unreacted 3-CBA was removed by hydrazine scavenger resin treatment. The omission of such a cleanup step from the subsequent literature suggests that removal of residual derivatising agent from the hapten derivative is not a necessary precaution prior to immunogen conjugation. The derivatised hapten was significantly larger than $\mathrm{AOZ}$ and so possessed enhanced immunogenicity, as well as a carboxy functional group which provided a means of conjugating to a carrier protein. While the resultant antisera displayed insufficient affinity to AOZ, it was found to bind nitrophenyl-AOZ (NPAOZ; Fig. 3). Optimum antiserum sensitivity $\left(\mathrm{IC}_{50}=0.3 \mu \mathrm{g} / \mathrm{L}\right)$ to $\mathrm{NPAOZ}$ was achieved by employing a low dose of immunogen $(0.05 \mathrm{mg})$ with 8 week rest periods between immunisations. The same immunogen was used [33] to produce monoclonal antibodies with sensitivities ranging from $0.52-1.15 \mu \mathrm{g} / \mathrm{L}$ for NPAOZ and this group also used a monoclonal antibody to detect NPAOZ in shrimp [9] and eggs [34]. In the former study [9] the authors attempted to develop haptens that would produce individual antibodies capable of binding AOZ, AHD and AMOZ by introducing aliphatic chains of 13 atoms between the respective epitope and protein. However the antisera were not capable of binding the target analytes, perhaps due to poor stability of the haptens, spacer binding effects or molecular size of the haptens as postulated by the authors. The 3-CPAOZ immunogen was also used by other workers [10] as a model antigen to compare the efficacy of three different adjuvants to raise polyclonal antisera in rabbits; on this occasion a wide range of antisera sensitivities were obtained with $20 \%$ of the rabbits immunised displaying $\mathrm{IC}_{50} \mathrm{~s}$ of $\leq 1 \mu \mathrm{g} / \mathrm{L}$.

Chang et al. [7] also derivatised AOZ, for polyclonal antisera production in rabbits, but did so using 4carboxybenzaldehyde (4-CBA) and by performing the reaction in a water/DMF mixture at room temperature (Fig. 4). The 4-CPAOZ product was purified with a simple water wash and the hapten structure confirmed by IR spectra and LC-MS/MS. This approach for hapten preparation could have potentially reduced steric hindrance following protein conjugation by increasing the distance between hapten and carrier and hence offering a clearer view of the $\mathrm{AOZ}$ epitope to the immune system. While insignificant binding to $\mathrm{AOZ}$ was detected and an $\mathrm{IC}_{50}$ of $18.3 \mu \mathrm{g} / \mathrm{L}$ was observed for NPAOZ, an $\mathrm{IC}_{50}$ of $1.05 \mu \mathrm{g} / \mathrm{L}$ was found for the benzaldehyde derivative, phenylAOZ (PAOZ).

Zhu et al. [35] continued the use of 4-CBA as the derivatising agent of $\mathrm{AOZ}$ for hapten preparation by reaction in acidified DMF at $60^{\circ} \mathrm{C}$ overnight. The product was extracted into ethyl acetate and purified by TLC and the hapten structure was confirmed by TLC, LC-MS/MS and NMR. Polyclonal antisera were again found to bind NPAOZ and the parent drug FZD, but not other nitrofuran drugs nor any of the metabolites, including AOZ.

A monoclonal antibody was produced by Zhou et al. [36], also using a 4-CPAOZ hapten, prepared by reaction in DMF at room temperature for $10 \mathrm{hr}$ followed by a water wash to purify. Interestingly, this antibody showed little cross-reactivity to NPAOZ but was sensitive to the CPAOZ hapten $\left(\mathrm{IC}_{50}=0.88 \mu \mathrm{g} / \mathrm{L}\right)$. In contrast, Le et al. [37] using 4-CPAOZ hapten produced a monoclonal antibody which displayed highest sensitivity to NPAOZ $\left(\mathrm{IC}_{50}=0.28 \mu \mathrm{g} / \mathrm{L}\right)$. On this occasion derivatisation of $\mathrm{AOZ}$ was achieved at $65^{\circ} \mathrm{C}$ in methanol overnight followed by an ethanol wash to purify. Similarly Liu et al. [38] produced a monoclonal antibody to detect AOZ in the form of NPAOZ using 4-CPAOZ as the hapten.

Various alternatives to CPAOZ haptens have been reported. Shen et al. [39] modified AOZ and 2-oxazolidinone using maleic anhydride at $-20^{\circ} \mathrm{C}$ with a lithium chloride and triethylamine catalyst in THF (Fig. 5). The products were extracted into ethyl acetate, washed, filtered and, after evaporation of the solvent, the residue was purified by silica gel column chromatography. The hapten structures were confirmed by MS and NMR and their carboxylic moieties were then modified before conjugation to carrier proteins. The monoclonal antibodies produced to these immunogens were reported to be specific to underivatised AOZ. A nitrophenyl-hexanoic acid derivative of AOZ (2-NP-HXA-AOZ) was employed by Cheng et al. [8] as a hapten (Fig. 6) to produce polyclonal antisera that could bind NPAOZ with an $\mathrm{IC}_{50}$ of $0.14 \mu \mathrm{g} / \mathrm{kg}$. FZD has also been used to prepare a hapten for AOZ monoclonal antibody production [40]. The nitro group on the parent drug was reduced to an amine which was then diazotised to allow coupling to a carrier protein.

Structural commonality of $\mathrm{AOZ}$ with other nitrofuran metabolites, specifically the available functional groups, led to the adoption of similar approaches to the preparation of haptens for AMOZ, AHD, SEM and DNSH. 


\subsection{AMOZ Haptens}

The first published report of an antibody to the FTD metabolite, AMOZ, was in 2009 [20] although a commercial AMOZ ELISA kit had been on the market since 2004. AMOZ was reacted, as was AOZ previously [5], by refluxing with 3-CBA in pyridine and the product was activated to allow coupling to the carrier protein.

Luo et al. [41] chose 4-CBA as the derivatising agent and reacted it with $\mathrm{AMOZ}$ in methanol at room temperature for $2 \mathrm{~h}$. Reaction progress was monitored by TLC and the product purified by the same technique. Formation of an active ester from the appended carboxylic acid provided the means to conjugate to the carrier protein. Monoclonal and polyclonal antibodies were produced, the best sensitivity to NPAMOZ being a polyclonal with $\mathrm{IC}_{50}=0.16 \mu \mathrm{g} / \mathrm{L}$. The same derivatising agent was used by Liu et al. [42] and Shu et al. [43]. Liu et al. also performed the reaction at room temperature but in a water/DMF mix for $6 \mathrm{~h}$. A water wash was used to purify the product which was confirmed by LC-MS. A monoclonal antibody was produced again with better sensitivity to NPAMOZ than CPAMOZ or AMOZ. Shu et al. modified AMOZ with 4-CBA in methanol at $60^{\circ} \mathrm{C}$ for $3 \mathrm{~h}$. The product was washed with methanol and verified by NMR; a monoclonal antibody was developed with optimum sensitivity to NPAMOZ.

A nitrophenyl-hexanoic acid derivative 2-NP-HXA-AMOZ, ((6-[4-[Nitro-3-[[[2-oxo-3-(5-morpholinomethyl)oxazolidinyl]imino]methyl]]phenoxyl] hexanoic acid, similar to one used by Cheng et al. [8] for AOZ, was employed by Sheu et al. [44] to produce antisera with good sensitivity to NPAMOZ.

Several workers have employed the use of a different derivatising agent, formylphenoxy acetic acid (FPA) with the aldehyde group at position -3 or -4 (Fig. 7). Song et al. [45] refluxed AMOZ with 4-FPA in methanol at $65^{\circ} \mathrm{C}$ overnight. The product was washed with ethanol and confirmed by NMR. While the monoclonal antibody produced was most sensitive to NPAMOZ $\left(\mathrm{IC}_{50}=0.17 \mu \mathrm{g} / \mathrm{L}\right)$ it also displayed sensitivity to underivatised AMOZ $\left(\mathrm{IC}_{50}=1.15 \mu \mathrm{g} / \mathrm{L}\right)$. Shen et al. [46] used 3-FPA to modify AMOZ in methanol at room temperature for 3 $\mathrm{h}$. The product was ethanol washed and its structure analysed by MS and NMR. The monoclonal antibody produced showed good sensitivity to NPAMOZ $\left(\mathrm{IC}_{50}=0.14 \mu \mathrm{g} / \mathrm{L}\right)$. Xu et al. [47] compared 3-CBA, 4-CBA, 3FPA and 4-FPA as derivatising agents when reacted with AMOZ in methanol at room temperature for $3 \mathrm{~h}$ to create four different haptens. The structures were assessed by MS and NMR and the haptens conjugated to BSA to prepare immunogens. The authors found that 3-FPA derivatisation of AMOZ produced the most sensitive polyclonal antibody to NPAMOZ $\left(\mathrm{IC}_{50}=2.1 \mu \mathrm{g} / \mathrm{L}\right)$.

Yan et al. [48] took an alternative approach by manipulating the parent drug, FTD, to create a hapten. They reduced the nitro group to an amine using zinc powder dissolved in acetonitrile and methanol acidified to $\mathrm{pH} 5$ while stirring at $40^{\circ} \mathrm{C}$ for $30 \mathrm{~min}$. The product was then conjugated to a carrier protein using gluteraldehyde as a cross-linker. This approach provided good sensitivity to AMOZ $\left(\mathrm{IC}_{50}=2.3 \mu \mathrm{g} / \mathrm{L}\right)$ but with substantial crossreactivity with FTD.

\subsection{AHD Haptens}

For the metabolite of NFT, AHD, the practice of derivatising with 4-CBA was continued by Xu et al. [25] to develop polyclonal antisera capable of binding the metabolite in the form of its benzaldehyde derivative (PAHD). Jiang et al. [22] also derivatised AHD with 4-CBA, in methanol at room temperature for $2 \mathrm{~h}$ with purification by TLC. On this occasion the monoclonal antibody produced was used to detect the nitrophenyl analogue, NPAHD $\left(\mathrm{IC}_{50}=0.68 \mu \mathrm{g} / \mathrm{L}\right)$. The same analogue was targeted by Chadseesuwan $e t$ al. [21]; however they opted for 3-CBA to modify AHD in pyridine, overnight at room temperature; the resultant monoclonal antibody provided an $\mathrm{IC}_{50}$ of $4.9 \mu \mathrm{g} / \mathrm{L}$.

\subsection{SEM Haptens}

Methods to prepare haptens for SEM, the metabolite of NFZ, have again relied on the derivatising agents 3$\mathrm{CBA}$ and 4-CBA. Cooper et al. [11] reacted SEM with 3-CBA at $37^{\circ} \mathrm{C}$ in pyridine overnight. Residual CBA was removed by hydrazine scavenger resin and the product was identified by LC-MS. Vass et al. $[15,59]$ used 3-CBA while Gao et al. [13] refluxed SEM overnight in pyridine with 4-CBA, the same reagent of choice reported in three other studies $[12,14,49]$. An alternative 2-oxoacetic acid derivative of SEM, 2[(aminocarbonyl)hydrazono] acetic acid was produced by Yin et al. [60] for use as an ELISA coating antigen but not as an immunogen hapten. 


\subsection{DNSH Haptens}

The marker metabolite of NFS is 3,5-dinitrosalicyclic acid hydrazide (DNSH). Shen et al. [26] prepared a glyoxylic acid derivative of DNSH by reaction in methanol at room temperature for $3 \mathrm{~h}$ (Fig. 8). Purification was by ethanol wash and the product was confirmed by MS and NMR. The protein-conjugated hapten produced polyclonal antisera displaying sensitivity to DNSH $\left(\mathrm{IC}_{50}=0.217 \mu \mathrm{mol} / \mathrm{L}\right)$ and high cross-reactivity with NFS.

\subsection{Parent Nitrofuran Haptens}

While most haptens have been designed to produce antibodies that bind the nitrofuran metabolites, there have been several reports of antibodies developed to detect the parent drugs in animal feed [27, 28, 31, 32], water [29] and in the eyes of poultry [30] as a means to reveal illegal use of the drugs.

Some of these studies have derivatised the corresponding metabolite to prepare a hapten to detect the parent compound [29, 31, 32]. Liu et al. [29] set out to produce an antibody that could bind the parent drug NFT. To do this they derivatised AHD with 3-CBA; the same method described above for haptens for detection of AHD in the form of PAHD [25] or NPAHD [21, 22]. Polyclonal antiserum with an $\mathrm{IC}_{50}$ of $3.2 \mu \mathrm{g} / \mathrm{L}$ for NFT was produced with understandably very high cross-reactivity to CPAHD [29].

A monoclonal antibody was produced to detect the parent drug FTD and its metabolite AMOZ [31]. This group had already used the same 3-FPA derivatisation of AMOZ [47] when producing an antibody to the metabolite. A similar approach was used by Zhang et al. [32] who derivatised AOZ with 4-FPA in order to produce an antibody for FZD detection.

Other workers have used structural mimics to create generic nitrofuran haptens $[27,28,30]$ that detect a range of parent drugs. A structural mimic, 5-nitrofurfural, was reacted with diamine sulphate at room temperature in ethanol and water [27] to create a suitable hapten (Fig. 9). The product was washed with water, verified by UV and IR spectra and then protein-conjugated to prepare an immunogen which produced antisera that could bind multiple nitrofurans. The same workers produced another generic hapten by reducing the nitro group of FZD to an amine by reaction in acetonitrile/methanol with zinc powder and $\mathrm{HCl}$ at $80^{\circ} \mathrm{C}$ until the solution turned red [28]. To facilitate conjugation the modified amine group was diazotised, by adding sodium nitrite in $\mathrm{HCl}$ and stirring for $2 \mathrm{~h}$ at $4^{\circ} \mathrm{C}$, before addition to the carrier protein. Polyclonal antisera produced in rabbits displayed superior sensitivity to the four major nitrofurans than the previous generic antiserum [27].

Thompson et al. [30] selected the hapten, 3-(5-nitro-2-furyl) acrylic acid, as a generic structural mimic for the four major nitrofuran drugs (Fig. 10). While possessing the generic nitro-furyl part of the nitrofuran structure the mimic also possessed a carboxylic acid group which allowed for direct conjugation to a carrier protein. The polyclonal antisera produced showed sensitivity to the four major nitrofurans and NFS with $\mathrm{IC}_{50}$ s ranging from 0.7 to $4.23 \mu \mathrm{g} / \mathrm{L}$.

\subsection{Haptens Summary}

Preparation of haptens for nitrofuran metabolites is not straightforward due to their lack of immunogenicity and difficulty in conjugating to carrier proteins. To resolve this, workers have employed derivatising agents which possess an aldehyde, to react with the amine on the nitrofuran analogue, and a carboxylic acid functional group to facilitate protein coupling. The derivatising agent also provides a spacer molecule between the epitope and carrier protein. Derivatisation of the nitrofuran metabolites using 3-CBA, 4-CBA, 3-FPA, 4-FPA and 2-NPHXA to prepare haptens generally results in the production of antibodies that display more affinity towards derivatives of the metabolites (nitrophenyl-, phenyl-, carboxyphenyl-) or the parent drugs rather than the metabolites themselves. Indeed some such antibodies have been used for detection of the parent nitrofurans [29, 31, 32]. The derivatising agents maleic anhydride and glyoxylic acid have been shown to create haptens for $\mathrm{AOZ}, \mathrm{AMOZ}$ and DNSH that provide adequate sensitivity to the underivatised metabolites themselves although in the case of AMOZ this was attributed to the poly-L-lysine carrier [50]. Table 1 summarises the range of derivatising agents and carrier proteins employed in the production of antibodies to various nitrofuran targets.

\subsection{Immunogen Conjugates}

The selection of nitrofuran derivatising agent allows for the introduction of a carboxylic acid into the hapten structure to enable coupling to a carrier protein for immunogen preparation. Invariably, in these circumstances, conjugation to the carrier protein has been achieved by performing one of two reactions: (i) a carbodiimide 
activation of the acid in conjunction with the addition of NHS to create an active ester species, or (ii) the anhydrous acid anhydride reaction using isobutyl chloroformate to create a mixed anhydride species. In both cases the active species produced reacts with primary amines on the carrier protein to form a strong amide bond. Two different carbodiimide reagents, 1-ethyl-3-(3-dimethylaminopropyl) carbodiimide hydrochloride (EDC) and $N, N$-dicyclohexylcarbdiimide (DCC), have been widely used for preparation of the NHS ester active species. One report used a generic nitrofuran (parent) mimic as the hapten [30] and, as it already possessed a carboxylic acid, derivatisation was not required and it was coupled directly to the ovalbumin carrier via EDC/NHS activation. Two alternatives to acid-amine coupling have been reported: gluteraldehyde was used to react amine with amine after mimic modification [27] and reduction of the nitro group of FTD [48], while in two other studies the nitro group of FZD was reduced to an amine and subsequently diazotised with sodium nitrite before reaction with the carrier protein amines [28, 40].

The majority of reports ( $88 \%$ ), which state the choice of carrier protein, employed an albumin, with bovine serum albumin (BSA) being the most popular (74\%); the remaining albumins were comprised of human serum albumin (HSA) and ovalbumin (OVA). There was also one reported use each of bovine thyroglobulin (BTG), porcine thyroglobulin (PTG), keyhole limpet hemocyanin (KLH) and poly-L-lysine dendrimer. The poly-Llysine dendrimer was compared with BSA for efficacy as a carrier for a glyoxalate derivative of AMOZ [50]. Antiserum produced by the BSA immunogen was not specific to free AMOZ while antiserum produced by the poly-L-lysine immunogen was specific. The authors concluded that poly-L-lysine dendrimer effectively improves the immunogenicity of small molecule haptens. Aside from this report and the high number of published papers favouring its use, there is no empirical evidence to indicate that BSA is demonstrably the most suitable carrier protein for nitrofuran antibody production.

A number of studies determined the rate of hapten incorporation of the carrier protein. This was performed by MALDI-ToF-MS analysis or, more commonly, by using the reagent, 2,4,6-trinitrobenzene sulfonic acid, which reacts with amines to produce a chromogenic product that can be measured at a specific wavelength under UV light. A range of incorporation ratios were reported, from 12.5:1 (hapten:protein) for coupling of AHD to BSA via 3-CBA [21] to 41:1 for coupling of AOZ to BSA via maleic anhydride [39]. The average incorporation ratio for albumin was 23:1 and there was a single report of an incorporation of 136:1 for SEM coupling to BTG; while this is a high rate, BTG has almost 3.5-fold more available amines than albumin. It is difficult to draw definitive conclusions on the significance of hapten incorporation rate on immunogen performance from the data available due to the variety of haptens and conjugation techniques employed. Comparison of three studies which determined incorporation rates of 24:1 [43], 27:1 [20] and 18:1 [48] for the coupling of AMOZ to BSA via 4-CBA, 3-CBA and glutaraldehyde produced antibodies with $\mathrm{IC}_{50} \mathrm{~S}$ of 5.6, 5.3 and $2.3 \mu \mathrm{g} / \mathrm{L}$ respectively. It therefore appears that a higher incorporation rate of hapten in the immunogen does not necessarily correspond to superior antibody sensitivity, often considered to be one of the most significant features of any binding molecule. 
Table 1. Derivatising agents selected to modify various hapten precursors; the parent drug or mimic chosen to act as hapten; the carrier protein selected; the conjugation reaction used to couple hapten and protein, and the analyte detected by the antibodies produced.

\begin{tabular}{|c|c|c|c|c|c|}
\hline Derivatising Agent & $\begin{array}{l}\text { Hapten/ } \\
\text { Precursor }\end{array}$ & Carrier & Conjugation & Analyte & References \\
\hline 3-CBA & $\begin{array}{l}\text { AOZ } \\
\text { AMOZ } \\
\text { AHD } \\
\text { SEM } \\
\end{array}$ & $\begin{array}{l}\text { HSA } \\
\text { BSA } \\
\text { BSA } \\
\text { BTG, BSA } \\
\end{array}$ & $\begin{array}{l}\text { Acid anhydride } \\
\text { Active ester } \\
\text { Active ester } \\
\text { Acid anhydride }\end{array}$ & $\begin{array}{l}\text { NPAOZ } \\
\text { AMOZ } \\
\text { NPAHD, NFT } \\
\text { CPSEM } \\
\end{array}$ & $\begin{array}{l}{[5][10][33]} \\
{[20]} \\
{[21][29]} \\
{[11][15]} \\
\end{array}$ \\
\hline 4-CBA & $\begin{array}{l}\mathrm{AOZ} \\
\text { AMOZ } \\
\text { AHD } \\
\text { SEM } \\
\end{array}$ & $\begin{array}{l}\text { BSA, KLH } \\
\text { BSA } \\
\text { BSA } \\
\text { BSA } \\
\end{array}$ & $\begin{array}{l}\text { Active ester } \\
\text { Active ester } \\
\text { Active ester } \\
\text { Active ester } \\
\end{array}$ & $\begin{array}{l}\text { PAOZ, NPAOZ, } \\
\text { CPAOZ } \\
\text { CPAMOZ } \\
\text { NPAHD } \\
\text { CPSEM } \\
\end{array}$ & $\begin{array}{l}{[7][35-38]} \\
{[41-43]} \\
{[22][25]} \\
{[12-14][49]} \\
\end{array}$ \\
\hline 3-FPA & AMOZ & BSA & Active ester & NPAMOZ, FTD & {$[31][46][47]$} \\
\hline 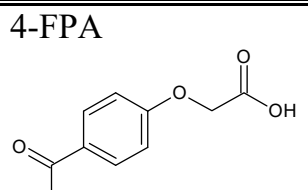 & $\begin{array}{l}\text { AOZ } \\
\text { AMOZ }\end{array}$ & $\begin{array}{l}\text { BSA } \\
\text { BSA }\end{array}$ & $\begin{array}{l}\text { Active ester } \\
\text { Active ester }\end{array}$ & $\begin{array}{l}\text { FZD } \\
\text { NPAMOZ }\end{array}$ & $\begin{array}{l}{[32]} \\
{[45]}\end{array}$ \\
\hline 2-NBA-Hex Acid & $\begin{array}{l}\text { AOZ } \\
\text { AMOZ }\end{array}$ & $\begin{array}{l}\text { OVA } \\
\text { PTG }\end{array}$ & $\begin{array}{l}\text { Active ester } \\
\text { Active ester }\end{array}$ & $\begin{array}{l}\text { NPAOZ } \\
\text { NPAMOZ }\end{array}$ & $\begin{array}{l}{[8]} \\
{[44]}\end{array}$ \\
\hline Maleic anhydride & $\mathrm{AOZ}$ & BSA & Active ester & $\mathrm{AOZ}$ & [39] \\
\hline Glyoxylic acid & $\begin{array}{l}\text { AMOZ } \\
\text { DNSH }\end{array}$ & $\begin{array}{l}\text { Polylysine } \\
\text { BSA }\end{array}$ & Active ester & $\begin{array}{l}\text { AMOZ } \\
\text { DNSH }\end{array}$ & $\begin{array}{l}{[50]} \\
{[26]}\end{array}$ \\
\hline $\begin{array}{l}\text { Diamine sulphate } \\
{\left[\mathrm{H}_{2} \mathrm{~N}=\mathrm{NH}_{2}\right] \mathrm{SO}_{4}}\end{array}$ & $\begin{array}{l}\text { 5- } \\
\text { nitrofurfural }\end{array}$ & BSA & Gluteraldehyde & $\begin{array}{l}\text { Parent } \\
\text { nitrofurans }\end{array}$ & {$[27]$} \\
\hline \multirow{4}{*}{ None } & FZD & BSA & $\begin{array}{l}\mathrm{NO}_{2} \text { reduction to } \mathrm{NH}_{2} \\
\text { then diazotisation }\end{array}$ & $\begin{array}{l}\text { Parent } \\
\text { nitrofurans }\end{array}$ & {$[28]$} \\
\hline & FZD & $\begin{array}{l}\text { BSA \& } \\
\text { OVA }\end{array}$ & $\begin{array}{l}\mathrm{NO}_{2} \text { reduction to } \mathrm{NH}_{2} \\
\text { then diazotisation }\end{array}$ & $\mathrm{AOZ}$ & {$[40]$} \\
\hline & FTD & $\mathrm{BSA}$ & $\begin{array}{l}\mathrm{NO}_{2} \text { reduction to } \mathrm{NH}_{2} \\
\text { then gluteraldehyde }\end{array}$ & AMOZ & {$[48]$} \\
\hline & $\begin{array}{l}\text { 3-(5-nitro-2- } \\
\text { furyl) } \\
\text { acrylic acid }\end{array}$ & OVA & Active ester & $\begin{array}{l}\text { Parent } \\
\text { nitrofurans }\end{array}$ & {$[30]$} \\
\hline
\end{tabular}




\section{NITROFURAN ANTIBODIES AND IMMUNOASSAYS}

\subsection{Mode of Antibody Production}

Reports of nitrofuran antibody production are split approximately equally between those harvesting polyclonal antisera (almost exclusively from immunised rabbits) and those developed via monoclonal hybridoma techniques involving immunisation of mice. A comparison of monoclonal antibodies, polyclonal antibodies and synthetic binders has been conducted previously for other challenging small molecule targets [51] with the main benefits of monoclonal antibodies being their suitability in performance, longevity of supply for diagnostic test kit manufacture and reduction in use of animals once the antibody has been produced. On direct comparison of monoclonal and polyclonal antibodies produced using the same immunogen, polyclonal antibodies tend to be superior in sensitivity. In the case of nitrofurans, this was demonstrated by the production of polyclonal antibodies to AMOZ which were up to five-fold more sensitive than monoclonal antibodies, depending on the ELISA format used [41]. One report [52] also described the modification of a monoclonal hybridoma [46] for the production of a novel recombinant single-chain variable fragment antibody to the target NPAMOZ which partially recognized the parent compound FTD ( $32 \%$ cross-reactivity) and was incorporated into a chemiluminescence ELISA [53]. The study [52] did not illustrate any benefit to assay sensitivity or reduction in the use of animals when using a recombinant antibody over traditional methods. However, linking genetic manipulation of hybridomas to antibody production and specific chemical binding sites could become an effective tool for the engineering of antibodies with desired cross-reactivity patterns for the range of nitrofuran compounds.

\subsection{Sample Preparation}

In general, both screening and confirmatory methods for nitrofuran metabolites in foods of animal origin use acid hydrolysis to release the tissue-bound markers, followed by derivatisation of the released metabolites. Derivatisation most commonly uses 2-nitrobenzaldehyde, occasionally 4-nitrobenzaldehyde, while benzaldehyde [25, 54], 4-carboxybenzaldehyde [14, 24] and a novel biotinylated-4-carboxybenzaldehyde [12] have also been used. The extraction techniques applied for the immunological detection of nitrofurans are fairly extensive with, in some cases, a pre-wash step, a derivatisation step ranging from $2 \mathrm{~h}$ to overnight, followed by a lipophilic wash step with hexane, then a solvent-solvent extraction using ethyl acetate or acetonitrile. The extraction steps required generally depend upon the specificity and sensitivity of the antibody for the target in question and the matrix under analysis. Some published methods [18, 19, 23, 26, 45, 55, 56], especially for immunochromatographic and biosensor applications, use no sample derivatisation. In these cases the authors claim that antibody sensitivity and specificity for the underivatised nitrofuran metabolites is sufficient such that, when methods are calibrated with underivatised standards, detection can be achieved to meet the MRPL. In such cases the sample clean up required may be more extensive, necessitating, for example, $\mathrm{C} 18$ solid phase extraction to achieve the desired result $[19,56]$. Reducing the extraction steps and moving to green chemistry solutions (minimising organic solvent usage) could be highly beneficial in both reducing sample preparation time and improving assay ease of use, which may enable greater use of portable assays for onsite analyses.

\subsection{Assay Formats for Immunological Methods}

The immunological detection of nitrofurans falls into two competitive assay formats: antigen-coated indirect assays and antibody-coated capture assays, the detection principle varying depending on the methodology applied. Immunological screening methods for nitrofurans described in the literature predominantly use ELISA. More recent endeavours in the design of immunochromatographic lateral flow immunoassays, biosensor methods and microarrays have also been described using similar immunoassay formats for individual and multiple nitrofuran targets.

\subsubsection{Enzyme, Chemiluminescent and Fluorophore-linked Immunosorbent Assays}

The ELISA format, first applied to AOZ in 2004, remains the most widely used and commercially viable methodology for immunological nitrofuran screening. Indirect competitive ELISA involves two binding processes: primary antibody and labelled antigen or secondary antibody. Microwell plates are coated with target antigen. Samples are added along with a primary antibody. The more antigen present in the sample, the less antibody will bind to the antigen immobilised on the well. An enzyme-labelled secondary antibody is then added followed by a substrate to elicit a chromogenic or fluorescent signal. Alternatively, in antibody coated 
competitive assays, primary antibody is coated on the plates before labelled antigen and free antigen compete for the binding to the antibody. The more antigen present in the sample, the less labelled antigen will bind to antibody immobilized on the well. The major advantage of a competitive ELISA format is the ability to assay crude or impure samples and still selectively detect antigen in the sample.

\subsubsection{AOZ Immunosorbent Assays}

The first ELISA for a nitrofuran compound was developed for determination of $\mathrm{AOZ}$ in prawns in an antigen capture assay with a limit of detection (LOD) of $0.1 \mu \mathrm{g} / \mathrm{kg}$ and a detection capability (CC $\beta$ ) of $<0.7 \mu \mathrm{g} / \mathrm{kg}$. The antiserum displayed insignificant cross-reactivity with three other major nitrofurans and their respective nitrophenyl derivatives; the only significant cross-reactivity (35\%) was to the parent drug, FZD [6]. Monoclonal antibodies produced using the same chemistry were employed in ELISAs for AOZ in eggs with a CC $\beta$ of 0.3 $\mu \mathrm{g} / \mathrm{kg}$ [34] and in pork, chicken, beef and shrimp muscle with a CC $\beta$ of $0.4 \mu \mathrm{g} / \mathrm{kg}$ and $17 \%$ cross-reactivity with FZD [9]. Chang et al. [7] published an ELISA for AOZ in various muscle and liver matrices with LODs of $0.3-$ $0.4 \mu \mathrm{g} / \mathrm{kg}$ and $6.2 \%$ cross-reactivity with FZD. Further polyclonal antibody ELISAs for AOZ in fish muscle exhibited LODs of $0.1-0.15 \mu \mathrm{g} / \mathrm{kg}$ with cross-reactivity to FZD of zero [8] and 5.9\% [54]. The determination of $\mathrm{AOZ}$ in muscle of various species by ELISA and time-resolved fluoroimmunoassay using a europium label has also been compared, with limits of detection of $0.11 \mu \mathrm{g} / \mathrm{L}$ and $0.07 \mu \mathrm{g} / \mathrm{L}$ respectively [37].

\subsubsection{AMOZ Immunosorbent Assays}

The first ELISA described for determination of AMOZ was for shrimps, applying an indirect ELISA format with LOD values of $0.1-0.3 \mu \mathrm{g} / \mathrm{kg}$ and $338 \%$ cross-reactivity to FTD [20]. A series of studies then investigated the use of different nitrofuran derivatives for immunogens and coating antigens in heterologous ELISA formats in order to improve the sensitivity of the tests. Monoclonal antibodies to AMOZ were raised using different derivatives including a novel phenoxyacetic, 2-(3-formylphenoxy) acetic acid (Fig. 7), which contained a methoxyacetic acid spacer [46]. Interestingly, when applied in an indirect ELISA format the homologous assay offered poorer sensitivity compared to the heterologous assay which used AMOZ derivatised with 2-oxoacetic acid as the coating antigen, indicating that using only a partial structure of the target molecule as the coating hapten may be a good strategy to improve immunoassay sensitivity [46]. The AMOZ LOD achieved was 0.01 $\mu \mathrm{g} / \mathrm{L}$ with only $4 \%$ cross-reactivity to FTD. Similarly, 2-NP-HXA-AMOZ was used as a novel hapten for the production of polyclonal antibodies and, when applied in an antigen capture ELISA coupled to HRP, achieved a LOD of $0.1 \mu \mathrm{g} / \mathrm{kg}$ for AMOZ in fish. No cross-reactivity to other nitrofuran compounds was observed [44]. Two novel haptens derivatised with 2-(4-formylphenoxy) acetic acid or 2-(3-formylphenoxy) acetic acid (Fig. 7) were compared against 3-carboxybenzaldehyle and 4-carboxybenzaldehyle derivatized AMOZ for raising polyclonal antibodies and acting as coating antigens. ELISA sensitivity was improved at least two-fold using the FPA derivatives, the differences in sensitivity being explained by computer-assisted molecular modelling of the lowest energy conformations of NPAMOZ and the immunising haptens [47]. The authors concluded that the introduction of the phenoxy spacer group in the FPA derivatives induced a conformational change in the morpholine ring of the $\mathrm{AMOZ}$ portion of the hapten in comparison with the CBA derivatives, bringing it into line with the conformation observed in free NPAMOZ, thus improving sensitivity of the subsequent antibodies to the target NPAMOZ. It is worth noting that molecular modelling has been utilised in the development of only one other nitrofuran antibody [15], in this case to the nitrophenyl derivative of semicarbazide (NPSEM). These authors demonstrated only a small charge distribution difference between the SEM moiety in the CPSEM hapten and the NPSEM target analyte, concluding that the absence of a $\mathrm{NO}_{2}$ group in the hapten would not significantly hinder binding to NPSEM. Molecular modelling offers various benefits in the design of immunoassays for low molecular weight food contaminants, as reviewed by Xu et al. [57], and there is scope for its further use in nitrofuran antibody development. The above study by Xu et al. [47] also confirmed the finding of Shen et al. [46] that use of AMOZ derivatised with 2-oxoacetic acid as a coating antigen (conjugated to ovalbumin) in an indirect heterologous ELISA format improved sensitivity, achieving LODs in fish and shrimp of 0.3 and 0.9 $\mu \mathrm{g} / \mathrm{kg}$ respectively [47]. This assay displayed cross-reactivity to FTD and AMOZ of $34.4 \%$ and $2.3 \%$ respectively. In a further study, haptens derived from 4-carboxybenzaldehyde and ethyl 4-bromobutyrate were used to produce monoclonal antibodies (the former hapten being more sensitive) and also applied as coating antigens in heterologous assay formats [43]. The authors suggested that a weakened conjugation effect improved the antibody recognition of NPAMOZ. Results showed that indirect ELISA sensitivity was improved about fifteen-fold when using a novel heterologous coating antigen at low hapten density. Cross-reactivity to FTD was $16.3 \%$ and ELISA LODs in fish, shrimp, chicken and pork were $0.22,0.15,0.29,0.34 \mu \mathrm{g} / \mathrm{kg}$, respectively. 
An indirect competitive chemiluminescence enzyme immunoassay based on a single-chain variable fragment (scFv) antibody against AMOZ derivative has been described [53]. These recombinant antibodies were produced [52] for detection of NPAMOZ but show no advantage over conventional antibody methods, although the chemiluminescence assay exhibited greater sensitivity than conventional ELISA. A LOD of $0.09 \mu \mathrm{g} / \mathrm{L}$ in shrimp was claimed, with $39 \%$ cross-reactivity to FTD. An indirect competitive chemiluminescence enzyme immunoassay using a monoclonal antibody raised against CPAMOZ was developed with an LOD of $0.01 \mu \mathrm{g} / \mathrm{L}$ and applied to fish, egg, honey and shrimp samples [42]. The same derivative was used to produce monoclonal and polyclonal antibodies applied in both indirect and antigen capture ELISA assays [41]. The polyclonal antibody in an antigen capture assay format offered the best sensitivity with LODs in chicken, pork, fish and shrimp below $0.06 \mu \mathrm{g} / \mathrm{kg}$ and negligible cross-reactivity with other nitrofurans including FTD. A further chemiluminescent ELISA for AMOZ determination in fish has been reported [16] showing a LOD of 0.012 $\mu \mathrm{g} / \mathrm{L}$ with $35 \%$ cross-reactivity to FTD.

Several ELISA methods have also been reported for direct determination of AMOZ without sample derivatisation [45, 48]. Song et al. [45] showed that in comparison to NPAMOZ, cross-reactivity of a monoclonal antibody with AMOZ was $15 \%$ (and 10\% for FTD). This cross-reactivity was sufficient to allow detection of AMOZ without the conventional sample derivatisation step. Similarly, when polyclonal antibodies were raised using a modified FTD hapten [48] it was reported that the structural similarity allowed direct detection of AMOZ without sample derivatisation. In this case, cross-reactivity to FTD was reported as $289 \%$ in comparison to AMOZ, while ELISA AMOZ LOD in muscle was $0.4 \mu \mathrm{g} / \mathrm{kg}$ [48]. For other nitrofuran targets such direct detection of the underivatised forms using highly sensitive antibodies could be a beneficial alternative to reduce sample preparation complexity and time.

\subsubsection{AHD Immunosorbent Assays}

To date significantly fewer ELISA methods have been described for the determination of AHD. An indirect ELISA using a monoclonal antibody raised to 4-CBA derivatized AHD was developed for determination of AHD in pork, fish, shrimp and chicken with LODs between 0.09 and $0.15 \mu \mathrm{g} / \mathrm{kg}$ [22] and negligible crossreactivity to NFT. Interestingly, the authors claim that homogenisation of the muscle tissue was not required prior to derivatisation as vigorous vortex mixing in $0.2 \mathrm{M}$ hydrochloric acid was sufficient to disrupt the tissue. Further validation would be required to prove the necessity or otherwise of homogenisation which is routinely applied to tissues prior to nitrofuran screening. A similar assay for shrimp, based on a monoclonal antibody raised against 3-CPAHD, was developed with an LOD of $0.11 \mu \mathrm{g} / \mathrm{kg}$ [21]. However, in this case the antibody exhibited high cross-reactivity to the parent NFT (876\%). A direct competitive chemiluminescent ELISA for AHD was also developed using a monoclonal antibody raised against 4-CPAHD but with the addition of a jeffamine linker. LODs of 0.1 and $0.28 \mu \mathrm{g} / \mathrm{kg}$ were achieved for fish and honey respectively with negligible cross-reactivity to other nitrofurans [58].

\subsubsection{SEM Immunosorbent Assays}

ELISAs have been developed for determination of SEM in chicken [11], pork and baby food [15] and eggs [59] using polyclonal antibodies raised against 3-CPSEM in antigen capture assays with $C C \beta$ values of $0.25,0.3$ and $0.3 \mu \mathrm{g} / \mathrm{kg}$, respectively. A more sensitive direct ELISA using a monoclonal antibody raised against 4-CPSEM [13] and employing biotin-modified CBA has been reported [12]. Sample SEM was derivatised with biotinylated 4-CBA and detected with horseradish peroxidase conjugated to streptavidin, yielding a LOD of $0.07 \mu \mathrm{g} / \mathrm{L}$ in milk powder. Furthermore, this ELISA required no sample extraction after derivatisation and centrifugation, providing a rapid and sensitive analysis for SEM. Further study of this biotinylated aldehyde derivatising agent in other matrices, and potentially for LC-MS/MS analyses, is warranted.

Improving the sensitivity of an indirect SEM ELISA in fish by greater than ten-fold through using a novel SEM derivative, 2-[(aminocarbonyl)hydrazono] acetic acid, as a heterologous coating antigen was also demonstrated by Yin et al. [60]. In the published antibodies for SEM, cross-reactivity with the parent compound NFZ is relatively small $(<10 \%)$, the largest being $21 \%$ [13]. 


\subsubsection{DNSH Immunosorbent Assays}

An indirect ELISA for DNSH, the marker metabolite of NFS, in chicken muscle is to date the only published immunoassay for this nitrofuran metabolite [26]. No sample derivatisation was required and the use of a heterologous coating antigen, 3,5-dinitrosalicyclic acid-ovalbumin, improved assay sensitivity fifty-fold. ELISA LOD for DNSH was $0.018 \mu \mathrm{mol} / \mathrm{L}$, with $315 \%$ cross-reactivity with NFS but none for the other four major nitrofuran metabolites.

\subsubsection{Parent Nitrofuran Immunosorbent Assays}

Nitrofuran medications are administered to animals via their feed or water at concentrations much higher than those found as metabolite residues in animal tissues. Consequently, the analytical MRPL of $1 \mu \mathrm{g} / \mathrm{kg}$ which was set by the European Commission for residues of metabolites in tissues does not apply to the parent nitrofurans. The parent nitrofuran drugs have been determined in animal feed by several authors using ELISA. FZD [32] and FTD [31] have been measured in feed by specific fluorescence immunoassays. However, generic antibodies are more useful for screening tests encompassing all the major nitrofuran drugs. A broad specificity generic enzyme immunoassay has been described which detects FZD, FTD, NFT and NFZ simultaneously in feed [28] at low LOD concentrations ranging from 0.2 to $2.1 \mu \mathrm{g} / \mathrm{kg}$ feed. An even broader ELISA for feed has been described [27] which claims to have sufficient cross-reactivity to screen for the five major nitrofurans plus the less common nifuroxazide and nifurstyrenate sodium with LODs from 5 to $16 \mu \mathrm{g} / \mathrm{kg}$. Only one report has been published specifically for detection of a nitrofuran in drinking water. NFT was determined at low concentrations (LOD $0.2 \mu \mathrm{g} / \mathrm{L}$ ) in water by ELISA [29] based on an antibody with sufficient cross-reactivity to detect NFT but having been raised against 3-CPAHD (cross-reactivity 1600\%).

\subsubsection{Immunochromatographic Assays}

Immunochromatographic strips are becoming increasingly common as rapid screening tools to enable portable onsite diagnostic testing. The principle of a one-step immunochromatographic assay (ICA) is based on the competitive reaction of coating antigen (plotted on a membrane test line) and target analyte for binding to limited antibody labelled with colloidal gold which generates the colour on the test line. The first published ICA for detection of a nitrofuran residue was developed for AHD in urine [25]. The intensity of colour on the test line is inversely related to the analyte concentration and the visual detection limit was found to be $10 \mu \mathrm{g} / \mathrm{L}$ in a $15 \mathrm{~min}$ assay. An ICA was then developed for AHD in pork with a visual LOD of $1.4 \mathrm{ng} / \mathrm{ml}$ [24]. The same research group also demonstrated a functionalized gold nanoparticle bio-barcode technology to detect SEM [49]. In this assay the hapten CPSEM was conjugated to bovine serum albumin as the coating antigen. Subsequently, gold nanoparticles dual-labelled with anti-CPSEM monoclonal antibodies and DNA oligonucleotides were synthesized via a one-step method. Enzymatic signal was converted to DNA signal by combining polymerase chain reaction with indirect competitive ELISA. The SEM LOD of this method reached $8 \mathrm{ng} / \mathrm{L}$, about 25 times more sensitive than conventional ELISA. The immunosorbent bio-barcode assay is a rapid screening tool adapted for ultra-high sensitive detection. Li et al. [56] developed a ICA for underivatised AMOZ in chicken and pork muscle and reported a visual LOD of $0.3 \mu \mathrm{g} / \mathrm{kg}$. The assay was based on a monoclonal antibody raised against AMOZ [45], used a colloidal gold-antibody probe and was applied to both meat and feed samples.

An ultrasensitive ICA was developed for AMOZ using surface-enhanced Raman spectroscopy (SERS) for direct detection in tissue and urine [19]. SERS is an emerging spectroscopy technology offering a non-destructive and ultrasensitive characterization down to the single molecule level and has been applied in areas such as chemical sensing medical diagnostics, the study of living cells and immunoassays. SERS-based immunoassays are usually applied in competitive format for the determination of small molecular compounds. In most SERS-based immunoassays, colloidal gold nanoparticles are used as the substrate for the preparation of an immunoprobe due to the easily controllable size distribution, long-term stability, friendly biocompatibility with antibodies and antigen, and sufficient enhancement of Raman intensity. Although the SERS-based detection technique provides a sensitive method for immobilized immunocomplexes, it has some drawbacks such as an extended incubation time for each binding step, inconvenient repetition of washing steps and difficulty in fabricating surfaces with highly reproducible enhancements. In this assay [19] the gold was coated with the Raman reporter molecule. The colour on the test and control lines generated from the gold label could be followed by the naked eye. The immunoprobes with the Raman reporter molecule captured by the coating antigen on the test line could be measured with a portable laser Raman Analyzer coupled to a microscope. A negative test would generate a 
higher intensity Raman signal at a specified wavelength compared to a positive test which would generate a lower signal in a manner similar to a gold label.

ICAs are cheap, cost effective tools fit for onsite screening analysis, although for the analysis of derivatised nitrofuran metabolites a simpler non-laboratory based sample preparation step is necessary. The use of antibodies to the underivatised nitrofuran metabolites is one solution to avoid this complication in sample preparation. However, highly sensitive antibodies are required, as currently most nitrofuran antibodies recognise primarily the nitrophenyl derivatives as a consequence of how they were raised and exhibit only minor crossreactivity to the underivatised forms.

\subsubsection{Biosensor Techniques}

A biosensor is an analytical device incorporating a biological or biologically-derived sensing element intimately associated with, or integrated within, a physicochemical transducer. The usual aim is to produce a digital electronic signal which is proportional to the concentration of a specific analyte or group of analytes [61]. To date there are limited publications on the use of biosensor technologies for the detection of nitrofuran compounds. Of the many biosensors that exist, the label-free impedimetric immunosensor eliminates the need for labelling reagents with an enzyme, offering a highly sensitive and responsive detection system for drug residues in food samples. The detection of AOZ was achieved by measuring the relative change in charge transfer resistance by electrochemical impedance spectroscopy before and after immunoreaction of $\mathrm{AOZ}$ and AOZ-monoclonal antibody [40]. Under the optimized conditions, this relative change in resistance was proportional to the logarithmic value of AOZ concentration in the range 20 to $10000 \mu \mathrm{g} / \mathrm{L}$. Moreover, the immunosensor had high selectivity for AOZ with no significant response to the metabolites of other nitrofurans and was suitable for AOZ determination in food samples including pork, crustaceans and eels. In recent years label-free impedimetric immunosensors have also been used for individual determination of AMOZ, SEM and AHD with LODs of 1.0, 1.0, $2.0 \mu \mathrm{g} / \mathrm{L}$ respectively $[18,55,23]$. The advantages of this type of impedimetric immunosensor are its sensitivity, wide linear range and stability while experimental results show its detection capability is comparable with that of LC-MS/MS. A multiplex biosensor assay for several parent nitrofurans based on optical surface plasmon resonance is also described below [30].

\subsubsection{Multiplex Analyses}

Multiplex analysis can be achieved in two main ways: generic antibodies or microarray approaches. A generic antibody or cocktail of antibodies can be applied to simultaneously detect compounds with high similarity in their molecular structure in a single assay. The drawback of this approach is that differentiation of specific compounds from other immunoreactive candidates cannot be achieved. In recent years microarray approaches have been applied when the structures of the target molecules differ significantly, preventing production of a single generic antibody, or where several highly specific antibodies to individual targets are available. For multiplex analyses one of the significant challenges is development of a single sample preparation protocol suitable for extracting all the target analytes.

An immunobiosensor assay based on optical surface plasmon resonance was developed for the multi-residue screening of a range of nitrofuran parent compounds in avian eyes [30]. A polyclonal antibody, raised against a nitrofuran mimic, cross-reacted with the five major parent nitrofurans and the biosensor method was reported to have a detection capability of less than $1 \mathrm{ng}$ per eye for NFZ, FZD, NFT and FTD, and 5 ng per eye for NFS.

The first reported assay for the simultaneous individual determination of the nitrofuran marker metabolites was a chemiluminescence-based biochip array sensing technique for the nitrophenyl derivatives of AOZ, AMOZ, AHD and SEM in honey with CC $\beta$ values of $<0.5 \mu \mathrm{g} / \mathrm{kg}$ for AOZ, AMOZ and AHD and $<0.9 \mu \mathrm{g} / \mathrm{kg}$ for SEM [62]. Biochip array technology is an alternative immunochemical-based detection platform that allows the immobilisation of up to 25 different ligand molecules (e.g. antibodies, proteins, oligonucleotides) on a biochip at specific locations called Discrete Test Regions (DTRs). The biochip array assay employs a competitive format. Antibodies selective for the analytes of interest are immobilised at the DTRs. Enzyme-labelled conjugate is then applied. When this conjugate is captured by the relevant antibody a complex is formed which emits light following addition of a signal reagent. Detection is accomplished via imaging of the chemiluminescent signal with a charge-coupled device camera. To date the cost of this biochip array approach in comparison with confirmatory analytical techniques has prohibited its wide scale uptake as a screening platform. 
Alternative microarray approaches have recently been investigated for nitrofuran residue screening. AOZ has been measured alongside various contaminants including malachite green, diethylstilbestrol and medroxyprogesterone in eels using a protein microarray [38]. The array comprised indirect assays in which coating antigens were immobilised on poly-L-lysine microarray glass slides. Primary antibody competed with the target analytes in standards or sample extracts before a secondary fluorescent-labelled antibody was applied. Slides were scanned using an Axon GenePix ${ }^{\circledR}$ 4000B microarray scanner to quantify the fluorescence signal. The LOD of AOZ in this multiplex assay was $0.103 \mu \mathrm{g} / \mathrm{kg}$ of eel.

Luminex Xmap Suspension Array technology has been used for the simultaneous quantification of AMOZ, AOZ, SEM and AHD in honey [63]. The analytes were coupled to BSA before coupling to carboxylated polystyrene microspheres. The method applied a biotin-streptavidin capture approach. A mixture of biotinylated antibodies specific for the four analytes, along with analyte standards or sample extracts, were incubated with the coupled microspheres at $37^{\circ} \mathrm{C}$ for $45 \mathrm{~min}$ before streptavidin-R-phycoerythrin was added. Analyte residues were quantified by measuring the mean fluorescence intensity. Assay LODs for AMOZ, AOZ, SEM, and AHD in honey were $0.087,0.031,0.055$, and $0.131 \mu \mathrm{g} / \mathrm{kg}$ respectively, and the suspension array method correlated well with commercially available immunoassay test kits.

Ongoing work by the current authors at Queen's University Belfast includes the development of a multiplex ELISA array for the simultaneous determination of AOZ, AMOZ, AHD, SEM and chloramphenicol. This platform has the ease of transfer and simplicity of use of current ELISA procedures with which the end user is already familiar [64]. A sciFLEXARRAYER S5 is used for spotting microwell plates and a sciReader CL colorimetric microarray reader used for scanning and analysing spot intensities. The challenge for this technology is in both the selection of appropriate antibody candidates for the assays and the evolution of userfriendly automated scanners which can handle, in a timely manner, the multiple calibration curves generated by multiplex assays.

\section{APPLICATION OF NITROFURAN IMMUNOASSAYS}

Of 46 publications identified which describe in-house nitrofuran immunoassays applied to test samples, it is notable that only 22 assays were applied to incurred samples, that is, samples known to have been treated with nitrofuran medications prior to sampling. The remaining assays utilised only manually fortified (spiked) samples prepared in the laboratory for validation purposes. This is a weakness in the validation of many tests for proteinbound residues such as the nitrofurans, since samples fortified with free nitrofuran metabolites give no indication of the efficacy of the hydrolysis procedure required to release bound nitrofuran metabolites from their in vivo protein-conjugated forms. Whenever possible, incurred samples, ideally with known nitrofuran concentrations from a chromatographic mass spectrometric reference method, should be tested to demonstrate the immunoassay test's applicability to real-world samples.

A wide range of sample types has been subjected to nitrofuran screening by immunoassay. Muscle of various species is the most common target: 35 immunoassay publications were identified, covering primarily porcine, avian, fish and crustacean muscle. Muscle is generally the target of choice for monitoring nitrofuran residues in the food chain. Immunoassays are also described for liver [7, 19, 45, 54], honey [18, 23, 40, 42, 55, 58, 62, 63], egg [18, 34, 42, 59], intestine/casings [18, 23, 40, 55], milk powder [12], baby food [15], kidney [45], eyes [30], urine [19, 25], plasma [54], water [29] and animal feed [27, 28, 31, 32, 56].

\section{COMMERCIAL NITROFURAN TEST KITS}

Table 2 lists the nitrofuran immunoassay test kits commercially available in 2016. Kits were identified, via online searching, from 21 manufacturers, although it is possible a few may be suppliers, not originating manufacturers. All manufacturers offer ELISA format test kits, with only two offering alternative immunoassaybased screening formats. Nankai Biotech offer separate qualitative lateral flow devices (LFD; that is, immunochromatographic assays) for the four major nitrofuran metabolites in muscle, seafood and honey, and a generic LFD for nitrofuran metabolites derived from medicated feed. Randox Food Diagnostics also offer antimicrobial array kits for their proprietary chemiluminescent Biochip Array System, covering, in a single test, the four major nitrofuran metabolites (and chloramphenicol) in muscle, shrimp and honey. It should be noted 
that, at time of writing, Charm have discontinued the $\mathrm{AOZ}$ and $\mathrm{AMOZ}$ in honey kits for their well-established Charm II radio-immunoassay based screening system. Of the 21 manufacturers currently offering ELISA kits, 15 offer separate kits for all four major nitrofuran metabolites. No rapid test is commercially available for screening of NFS or its marker residue DNSH. Zhongshan Yueer Biotechnology is the only manufacturer to offer a single ELISA test based on a cocktail of antibodies to several nitrofuran metabolites. However, no further information could be sourced to judge the performance of this kit. Presumably the technical issues (primarily non-specific binding) inherent in using cocktails of specific antibodies in single immunoassays and the desire for a screening result which specifies the particular analyte detected, have discouraged the development of such cocktail tests for a group of nitrofuran antibiotics.

There are test kits available with validation claimed for all matrices in which nitrofuran residues have been detected, including edible animal tissues (red meats, chicken, shrimp/seafood, fish, liver, casings) and animal produce (milk, honey, eggs), in addition to bodily fluids (serum, urine) and animal feeds. Test kit limits of detection range from 0.01 to $0.5 \mu \mathrm{g} / \mathrm{kg}$ sample, comfortably satisfying the EU MRPL for nitrofuran tests and the EU Reference Point for Action of $1 \mu \mathrm{g} / \mathrm{kg}$. It is clear from Table 2 that, if commercial supply and demand is a reliable indicator, microwell plate ELISA still remains the nitrofuran screening format of choice for those without access to sophisticated mass spectrometry facilities. Lateral Flow Devices have not been widely adopted for rapid nitrofuran detection (currently only one commercial supplier), possibly because the necessarily lengthy tissue sample preparation (hydrolysis, derivatisation and extraction) negates the time saving of a rapid LFD analysis. Furthermore, for the detection of banned, carcinogenic residues such as nitrofurans, users may require more than the qualitative or semi-quantitative result LFDs can provide.

The first commercially available immunoassay kits for nitrofurans were ELISA kits for AOZ and AMOZ launched by R-Biopharm in 2004. These kits have since been the subject of evaluation in the literature [65, 66, $67,68]$ and application to a range of foods and have been applied in a residue depletion study [66] and a retail screening survey [69]. Evaluations have also been published of AHD and SEM ELISA kits manufactured by Randox [68] and four kits (not currently available) from WDWK Biotech [70]. AOZ and AMOZ kits from Bioo Scientific have also been applied in a survey of aquaculture feed and fish [71]. 
Table 2. Commercially available immunoassay test kits for nitrofuran analysis.

\begin{tabular}{|c|c|c|c|c|c|}
\hline Supplier & Supplier URL & Test format & Targets * & Validated matrices ** & Limits of detection $(\mathrm{ng} / \mathrm{g}) * *$ \\
\hline Abraxis & www.abraxiskits.com & ELISA & AOZ, AMOZ, AHD, SEM & shrimp, fish, chicken, egg, milk, honey, feed & $0.06-0.3$ \\
\hline Alpha Diagnostics & www.4adi.com & ELISA & AOZ, AMOZ, AHD, SEM & fish, shrimp, honey, chicken meat/liver, milk & $0.05-0.3$ \\
\hline Asurgreen & www.asurgreen.com & ELISA & AOZ, AMOZ, AHD, SEM & milk, serum, urine, feed, fish, shrimp, meat, eggs, honey & - \\
\hline BIOO Scientific & www.biooscientific.com & ELISA & AOZ, AMOZ, AHD, SEM & feed, fish, shrimp, meat, eggs, honey, milk, serum, urine & $0.04-0.05$ \\
\hline Biorex & www.biorexfooddiagnostics.com & ELISA & $\mathrm{AOZ}, \mathrm{AMOZ}$ & muscle, seafood, honey & 0.1 \\
\hline Creative Diagnostics & www.creative-diagnostics.com & ELISA & AHD, SEM & feed, fish, shrimp, beef, chicken, pork, eggs, honey, milk, serum, urine & $0.1-0.3$ \\
\hline Europroxima & www.europroxima.com & ELISA & AOZ, AMOZ, AHD, SEM & muscle, liver, shrimps, fish, egg, milk, honey, urine & $0.05-0.5$ \\
\hline Huaan Magnech Bio-Tech & en.magnech.com & ELISA & AOZ, AMOZ, AHD & animal tissue, aquatic products, liver, honey, milk & $0.1-0.2$ \\
\hline Krishgen Biotechnology & www.krishgen.com & ELISA & AHD, SEM & tissues, liver, milk, intestine, fish, shrimp, honey & $0.1-0.15$ \\
\hline Libios & www.libios.fr & ELISA & $\mathrm{AOZ}, \mathrm{AMOZ}$ & muscle, seafood, crustaceans & 0.05 \\
\hline \multirow[t]{2}{*}{ Nankai Biotech } & www.nkbiotech.en.china.cn & ELISA & AOZ, AMOZ, AHD, SEM & tissue, aquatic products, feed, honey & $0.1-0.3$ \\
\hline & & Lateral Flow Device & AOZ, AMOZ, AHD, SEM & honey, livestock, poultry, seafood, fish, eggs & $0.2-2$ \\
\hline \multirow[t]{2}{*}{ Randox Food Diagnostics } & www.randoxfooddiagnostics.com & ELISA & AOZ, AMOZ, AHD, SEM & aquaculture, meat & $0.06-0.4$ \\
\hline & & Chemiluminescent Biochip Array & AOZ-AMOZ-AHD-SEM *** & shrimp, meat, honey & $0.06-0.5$ \\
\hline R-Biopharm & www.r-biopharm.com & ELISA & AOZ, AMOZ, AHD, SEM & shrimp, meat, liver, fish, whole egg, milk & $0.05-0.4$ \\
\hline Reagen & www.reagen.us & ELISA & AOZ, AMOZ, AHD, SEM & feed, fish, eggs, honey, meat, milk, milk powder, serum, shrimp, urine & $0.01-0.1$ \\
\hline Romer Labs & www.romerlabs.com & ELISA & AOZ, AMOZ, AHD, SEM & shrimp, chicken, fish, urine, honey & $0.06-0.43$ \\
\hline Shenzhen Lvshiyun Biotech & www.lsybt.com & ELISA & AOZ, AMOZ, AHD, SEM & muscle, liver, honey, milk, intestine, urine, fish, shrimp & $0.04-0.3$ \\
\hline Tecna & www.tecnalab.it & ELISA & $\mathrm{AOZ}, \mathrm{AMOZ}$ & muscle, crustaceans, honey & 0.05 \\
\hline Unibiotest & www.unibiotest.com & ELISA & AOZ, AMOZ, AHD, SEM & tissue, liver, honey, intestine, shrimp, fish & 0.3 \\
\hline \multirow[t]{2}{*}{ Zhongshan Yueer Biotech } & www.yueerbio.com & ELISA & AOZ, AMOZ, AHD, SEM & muscle, liver, fish, shrimp, honey & 0.1 \\
\hline & & ELISA & AOZ-AMOZ-AHD-SEM **** & muscle, liver, fish, shrimp, honey & 0.1 \\
\hline
\end{tabular}

*Separate kits unless stated. **Not applicable to all kits. ***Multiplex assay. ****Single "cocktail" ELISA.

Note: Cusabio Biotech and MyBiosource also supply separate ELISA kits for AOZ, AMOZ, AHD and SEM but no specifications available online. 


\section{FUTURE NEEDS}

While screening of the food chain for residues of nitrofuran antibiotics is now well established, several technical and toxicological issues would benefit from further development.

(i) Despite previously widespread use of nifursol in the poultry industry, screening for its marker residue DHSH is rarely included in laboratory testing suites. Development of further antibodies to DHSH and adoption of nifursol monitoring programmes, particularly in avian species, would address this anomaly [2].

(ii) Development of generic antibodies binding two or more derivatised nitrofuran metabolites would reduce screening costs and time for ELISA/ICA format tests and potentially broaden the scope of nitrofuran monitoring. For laboratories with more sophisticated instrumentation, further development of multiplexed antibody techniques will serve a similar purpose.

(iii) Development of antibodies with sufficient sensitivity to bind the underivatised nitrofuran metabolites after their release from samples by hydrolysis could be of benefit if hydrolysis times and extraction procedures can be minimized. Such developments may pave the way for greater application of rapid semi-quantitative ICA tests in nitrofuran monitoring.

(iv) For immunological methods to compete with mass spectrometry as nitrofuran screening tools, the key challenge is portability. Major advances in rapid and robust "green chemistry" sample preparation methods are required to enable portable multiplex detection platforms suitable for novice ends users outside the laboratory and to improve sample turnaround times at inspection points.

(v) There have recently been calls for a modern toxicological risk assessment of nitrofurans in food to be carried out [2] and, in particular, a comprehensive carcinogenicity study of SEM [3].

(vi) There remains a need to identify an alternative to SEM as the marker residue for nitrofurazone abuse due to potential other sources of SEM in food. Until such a marker is found, those using immunoassay or confirmatory analyses for SEM should follow available guidance to minimise false positive results [2].

\section{ACKNOWLEDGEMENTS}

Grateful thanks are expressed to Professor Glenn Kennedy, formerly of the Agri-Food and Biosciences Institute (Belfast, UK) for assistance in reviewing the literature, for pioneering the production of antibodies to nitrofuran metabolites and shaping the global response to nitrofuran residues in the food chain.

\section{REFERENCES}

[1] Vass, M.; Hruska, K.; Franek, M. Nitrofuran antibiotics: a review on the application, prohibition and residual analysis. Vet. Med. 2008, 53, 469-500.

[2] Points, J.; Thorburn Burns, D.; Walker, M.J. Forensic issues in the analysis of trace nitrofuran veterinary residues in food of animal origin. Food Control 2015, 50, 92-103.

[3] EFSA CONTAM Panel (EFSA Panel on Contaminants in the Food Chain). Scientific Opinion on nitrofurans and their metabolites in food. EFSA J., 2015, 13(6), 4140, 217pp. doi:10.2903/j.efsa.2015.4140.

[4] Cooper, K.; Mulder, P.; van Rhijn, J.; Kovacsics, L.; McCracken, R.; Young, P.; Kennedy, D. Depletion of four nitrofuran antibiotics and their tissue-bound metabolites in porcine tissues and determination using LC-MS/MS and HPLC-UV. Food Addit. Contam. 2005, 22, 406-414.

[5] Cooper, K.M.; Caddell, A.; Elliott, C.T.; Kennedy, D.G. Production and characterisation of polyclonal antibodies to a derivative of 3-amino-2-oxazolidinone, a metabolite of the nitrofuran furazolidone. Anal. Chim. Acta 2004, 520, 79-86.

[6] Cooper, K.M.; Elliott, C.T.; Kennedy, D.G. Detection of 3-amino-2-oxazolidinone (AOZ), a tissue-bound metabolite of the nitrofuran furazolidone, in prawn tissue by enzyme immunoassay. Food Addit. Contam. 2004, 21, 841-848.

[7] Chang, C.; Peng, D.; Wu, J.; Wang, Y.; Yuan, Z. Development of an indirect competitive ELISA for the detection of furazolidone marker residue in animal edible tissues. J. Agric. Food Chem. 2008, 56, 1525-1531.

[8] Cheng, C.; Hsieh, K.; Lei, Y.; Tai, Y.; Chang, T.; Sheu, S.; Li, W.; Kuo, T. Development and Residue Screening of the Furazolidone Metabolite, 3-Amino-2-oxazolidinone (AOZ), in Cultured Fish by an Enzyme-Linked Immunosorbent Assay. J. Agric. Food Chem. 2009, 57, 5687-5692.

[9] Diblikova, I.; Cooper, K.M.; Kennedy, D.G.; Franek, M. Monoclonal antibody-based ELISA for the quantification of nitrofuran metabolite 3-amino-2-oxazolidinone in tissues using a simplified sample preparation. Anal. Chim. Acta 2005, 540, 285-292.

[10] Fodey, T.L.; Delahaut, P.; Charlier, C.; Elliott, C.T. Comparison of three adjuvants used to produce polyclonal antibodies to veterinary drugs. Vet. Immunol. Immunopathol. 2008, 122, 25-34.

[11] Cooper, K.M.; Samsonova, J.V.; Plumpton, L.; Elliott, C.T.; Kennedy, D.G. Enzyme immunoassay for semicarbazide The nitrofuran metabolite and food contaminant. Anal. Chim. Acta 2007, 592, 64-71.

[12] Fang, Z.; Jiang, B.; Wu, W.; Xiang, Z.; Ouyang, C.; Huang, T.; Chen, J.; Zeng, L. ELISA detection of semicarbazide based on a fast sample pretreatment method. Chemical Communications 2013, 49, 6164-6166.

[13] Gao, A.; Chen, Q.; Cheng, Y.; Lei, J.; Zeng, L. Preparation of monoclonal antibodies against a derivative of semicarbazide as a metabolic target of nitrofurazone. Anal. Chim. Acta 2007, 592, 58-63. 
[14] Tang, Y.; Xu, J.; Wang, W.; Xiang, J.; Yang, H. A sensitive immunochromatographic assay using colloidal goldantibody probe for the rapid detection of semicarbazide in meat specimens. European Food Research and Technology 2011, 232, 9-16.

[15] Vass, M.; Diblikova, I.; Cernoch, I.; Franek, M. ELISA for semicarbazide and its application for screening in food contamination. Anal. Chim. Acta 2008, 608, 86-94.

[16] Dai Jin-Bo; Xu Zhen-Lin; Liu Feng-Yin; Yang Jin-Yi; Sun Yuan-Ming; Wang Hong; Lei Hong-Tao; Shen Yu-Dong Determination of Furaltadone Metabolite in Fish by Chemiluminescence Enzyme Immunoassay. Chinese Journal of Analytical Chemistry 2015, 43, 871-875.

[17] George, S.E.; Elliott, C.T.; McLaughlin, D.P.; Delahaut, P.; Akagi, T.; Akashi, M.; Fodey, T.L. An investigation into the potential use of nanoparticles as adjuvants for the production of polyclonal antibodies to low molecular weight compounds. Vet. Immunol. Immunopathol. 2012, 149, 46-53.

[18] Jin, W.; Yang, G.; Wu, L.; Wang, Q.; Shao, H.; Qin, A.; Yu, B.; Li, D.; Cai, B. Detecting 5-morpholino-3-amino-2oxazolidone residue in food with label-free electrochemical impedimetric immunosensor. Food Control 2011, 22, 16091616.

[19] Li, M.; Yang, H.; Li, S.; Liu, C.; Zhao, K.; Li, J.; Jiang, D.; Sun, L.; Wang, H.; Deng, A. An ultrasensitive competitive immunochromatographic assay (ICA) based on surface-enhanced Raman scattering (SERS) for direct detection of 3amino-5-methylmorpholino-2-oxazolidinone (AMOZ) in tissue and urine samples. Sensors and Actuators B-Chemical 2015, 211, 551-558.

[20] Pimpitak, U.; Putong, S.; Komolpis, K.; Petsom, A.; Palaga, T. Development of a monoclonal antibody-based enzymelinked immunosorbent assay for detection of the furaltadone metabolite, AMOZ, in fortified shrimp samples. Food Chem. 2009, 116, 785-791.

[21] Chadseesuwan, U.; Puthong, S.; Gajanandana, O.; Palaga, T.; Komolpis, K. Development of an Enzyme-Linked Immunosorbent Assay for 1-Aminohydantoin Detection. J. AOAC Int. 2013, 96, 680-686.

[22] Jiang, W.; Luo, P.; Wang, X.; Chen, X.; Zhao, Y.; Shi, W.; Wu, X.; Wu, Y.; Shen, J. Development of an enzyme-linked immunosorbent assay for the detection of nitrofurantoin metabolite, 1-amino-hydantoin, in animal tissues. Food Control 2012, 23, 20-25.

[23] Jin, W.; Yang, G.; Shao, H.; Qin, A. A label-free impedimetric immunosensor for detection of 1-aminohydantoin residue in food samples based on sol-gel embedding antibody. Food Control 2014, 39, 185-191.

[24] Tang, Y.; Xu, X.; Liu, X.; Huang, X.; Chen, Y.; Wang, W.; Xiang, J. Development of a Lateral Flow Immunoassay (LFA) Strip for the Rapid Detection of 1-Aminohydantoin in Meat Samples. J. Food Sci. 2011, 76, T138-T143.

[25] Xu, Y.P.; Liu, L.Q.; Li, Q.S.; Peng, C.F.; Chen, W.; Xu, C.L. Development of an immunochromatographic assay for rapid detection of 1-Aminohydantoin in urine specimens. Biomedical Chromatography 2009, 23, 308-314.

[26] Shen, Y.; Zhang, S.; Lei, H.; Wang, H.; Xiao, Z.; Jiang, Y.; Sun, Y. Design and synthesis of Immunoconjugates and development of an indirect ELISA for rapid detection of 3,5-dinitrosalicyclic acid hydrazide. Molecules 2008, 13, 22382248.

[27] Li, J.; Liu, J.; Zhang, H.; Li, H.; Wang, J. Broad specificity indirect competitive immunoassay for determination of nitrofurans in animal feeds. Anal. Chim. Acta 2010, 678, 1-6.

[28] Li, J.; Liu, J.X.; Wang, J.P. Multidetermination of Four Nitrofurans in Animal Feeds by a Sensitive and Simple EnzymeLinked Immunosorbent Assay. J. Agric. Food Chem. 2009, 57, 2181-2185.

[29] Liu, W.; Zhao, C.; Zhang, Y.; Lu, S.; Liu, J.; Xi, R. Preparation of polyclonal antibodies to a derivative of 1aminohydantoin (AHD) and development of an indirect competitive ELISA for the detection of nitrofurantoin residue in water. J. Agric. Food Chem. 2007, 55, 6829-6834.

[30] Thompson, C.S.; Traynor, I.M.; Fodey, T.L.; Crooks, S.R.H.; Kennedy, D.G. Screening method for the detection of a range of nitrofurans in avian eyes by optical biosensor. Anal. Chim. Acta 2011, 700, 177-182.

[31] Xu, Z.; Zhang, S.; Sun, Y.; Shen, Y.; Lei, H.; Jiang, Y.; Eremin, S.A.; Yang, J.; Wang, H. Monoclonal Antibody-Based Fluorescence Polarization Immunoassay for High Throughput Screening of Furaltadone and its Metabolite AMOZ in Animal Feeds and Tissues. Comb. Chem. High Throughput Screen. 2013, 16, 494-502.

[32] Zhang, S.; Shen, Y.; Sun, Y. Monoclonal antibody-based fluorescence polarization immunoassay for furazolidone in feed. Anal. Lett. 2010, 43, 2716-2729.

[33] Vass, M.; Kotkova, L.; Diblikova, I.; Nevorankova, Z.; Cooper, K.M.; Kennedy, D.G.; Franek, M. Production and characterisation of monoclonal antibodies for the detection of AOZ, a tissue bound metabolite of furazolidone. Vet. Med. 2005, 50, 300-310.

[34] Franek, M.; Diblikova, I.; Vass, M.; Kotkova, L.; Stastny, K.; Frgalova, K.; Hruska, K. Validation of a monoclonal antibody-based ELISA for the quantification of the furazolidone metabolite (AOZ) in eggs using various sample preparation. Vet. Med. 2006, 51, 248-257.

[35] Zhu, H.P.; Liu, T.T.; Liu, B.; Yin, H.L.; Li, X.L.; Wang, L.; Wang, S. Antigens synthesis and antibodies preparation for furazolidone and its metabolite 3-amino-2-oxazolidinone. Chinese Chemical Letters 2010, 21, 1049-1052.

[36] Zhou, K.-.; Tang, Y.; Lan, C.-.; Shi, C.-.; Fu, Q.-.; Liang, J.-. Preparation of monoclonal antibody against furazolidone metabolite and novel immunochromatographic strips. Chinese Journal of Biologicals 2014, 27, 927-931.

[37] Le, T.; Yu, H. Determination of 3-Amino-2-oxazolidinone in Animal Tissue by an Enzyme-Linked Immunosorbent Assay and a Time-Resolved Fluoroimmunoassay. Anal. Lett. 2015, 48, 1275-1284. 
[38] Liu, Y.-.; Wang, Q.; Jiang, W.; Chen, Y.-.; Zhao, X.-.; Jing, Z.-.; Zhang, M. Simultaneous Determination of Malachite Green, Diethylstilbestrol, Medroxyprogesterone, and 3-Amino-2-Oxazolidone in Synbranchoid Eels by a Protein Microarray Method. Food Analytical Methods 2015, 8, 1058-1066.

[39] Shen, Y.D.; Wang, Y.; Zhang, S.W.; Xiao, Z.L.; Sun, Y.M.; Bu, X.Z.; Gu, L.Q. Design and efficient synthesis of novel haptens and complete antigens for the AOZ, a toxic metabolite of furazolidone. Chinese Chemical Letters 2007, 18, 1490-1492.

[40] Yang, G.; Jin, W.; Wu, L.; Wang, Q.; Shao, H.; Qin, A.; Yu, B.; Li, D.; Cai, B. Development of an impedimetric immunosensor for the determination of 3-amino-2-oxazolidone residue in food samples. Anal. Chim. Acta 2011, 706, 120-127.

[41] Luo, P.J.; Jiang, W.X.; Beier, R.C.; Shen, J.Z.; Jiang, H.Y.; Miao, H.; Zhao, Y.F.; Chen, X.; Wu, Y.N. Development of An Enzyme-Linked Immunosorbent Assay for Determination of the Furaltadone Etabolite, 3-Amino-5-

Morpholinomethyl-2-Oxazolidinone (AMOZ) in Animal Tissues. Biomedical and Environmental Sciences 2012, 25, 449-457.

[42] Liu, Y.; Jiang, W.; Chen, Y.; Xiao, Y.; Shi, J.; Qiao, Y.; Zhang, H.; Li, T.; Wang, Q. A novel chemiluminescent ELISA for detecting furaltadone metabolite, 3-amino-5-morpholinomethyl-2-oxazolidone (AMOZ) in fish, egg, honey and shrimp samples. J. Immunol. Methods 2013, 395, 29-36.

[43] Shu, J.; He, L.; Ding, H.; Wang, L.; Guo, H.; Gao, Y.; Dzakah, E.E.; Zeng, Z. Synthesis of furaltadone metabolite, 3amino-5-morpholinomethyl-2-oxazolidone (AMOZ) and novel haptens for the development of a sensitive enzyme-linked immunosorbent assay (ELISA). Analytical Methods 2014, 6, 2306-2313.

[44] Sheu, S.; Tai, Y.; Li, W.; Lei, Y.; Hsieh, K.; Lin, C.; Cheng, C.; Chang, T.; Kuo, T. Development of a Competitive ELISA for the Detection of a Furaltadone Marker Residue, 3-Amino-5-Morpholinomethyl-2-Oxazolidinone (AMOZ), in Cultured Fish Samples. Journal of Veterinary Medical Science 2012, 74, 1439-1446.

[45] Song, J.; Yang, H.; Wang, Y.; Si, W.; Deng, A. Direct detection of 3-amino-5-methylmorpholino-2-oxazolidinone (AMOZ) in food samples without derivatisation step by a sensitive and specific monoclonal antibody based ELISA. Food Chem. 2012, 135, 1330-1336.

[46] Shen, Y.; Xu, Z.; Zhang, S.; Wang, H.; Yang, J.; Lei, H.; Xiao, Z.; Sun, Y. Development of a Monoclonal AntibodyBased Competitive Indirect Enzyme-Linked Immunosorbent Assay for Furaltadone Metabolite AMOZ in Fish and Shrimp Samples. J. Agric. Food Chem. 2012, 60, 10991-10997.

[47] Xu, Z.; Shen, Y.; Sun, Y.; Campbell, K.; Tian, Y.; Zhang, S.; Lei, H.; Jiang, Y. Novel hapten synthesis for antibody production and development of an enzyme-linked immunosorbent assay for determination of furaltadone metabolite 3amino-5-morpholinomethyl-2-oxazolidinone (AMOZ). Talanta 2013, 103, 306-313.

[48] Yan, X.D.; Hu, X.Z.; Zhang, H.C.; Liu, J.; Wang, J.P. Direct determination of furaltadone metabolite, 3-amino-5morpholinomethyl-2-oxazolidinone, in meats by a simple immunoassay. Food Agric. Immunol. 2012, 23, $203-215$.

[49] Tang, Y.; Yan, L.; Xiang, J.; Wang, W.; Yang, H. An immunoassay based on bio-barcode method for quantitative detection of semicarbazide. European Food Research and Technology 2011, 232, 963-969.

[50] Liu, F.Y.; Shen, Y.D.; Xiao, Z.L.; Yang, J.Y.; Sun, Y.M.; Wang, H.; Lei, H.T.; Xu, Z.L. Enhancing the immunogenicity of hapten 3-Amino-5-morpholinomethyl -2-oxazolidone (AMOZ) using dendrimer as a carrier. Modern Food Science and Technology 2015, 31, 31-36.

[51] Campbell, K.; Rawn, D.F.K.; Niedzwiadek, B.; Elliott, C.T. Paralytic shellfish poisoning (PSP) toxin binders for optical biosensor technology: Problems and possibilities for the future: A review. Food Addit. Contam. Part A Chem., Anal., Control, Expo. Risk Assess. 2011, 28, 711-725.

[52] Yang, W.; Wang, H.; Dong, J.; Xu, Z.; Shen, Y.; Sun, Y.; Liu, X.; Li, Z.; Lei, H.; Du, X. Cloning, expression, purification, and characterization of a novel single-chain variable fragment antibody against the 2-nitrobenzaldehyde derivative of a furaltadone metabolite in Escherichia coli. Protein Expr. Purif. 2012, 84, 140-146.

[53] Yang Wu-Ying; Dong Jie-Xian; Shen Yu-Dong; Yang Jin-Yi; Wang Hong; Xu Zhen-Lin; Yang Xing-Xing; Sun YuanMing Indirect Competitive Chemiluminescence Enzyme Immunoassay for Furaltadone Metabolite in Metapenaeus Ensis. Chinese Journal of Analytical Chemistry 2012, 40, 1816-1821.

[54] Liu, Y.; Peng, D.; Huang, L.; Wang, Y.; Chang, C.; Ihsan, A.; Tao, Y.; Yang, B.; Yuan, Z. Application of a modified enzyme-linked immunosorbent assay for 3-amino-2-oxazolidinone residue in aquatic animals. Anal. Chim. Acta 2010, 664, 151-157.

[55] Jin, W.-.; Yang, G.-.; Shao, H.-.; Qin, A.-. A novel label-free impedimetric immunosensor for detection of semicarbazide residue based on gold nanoparticles-functional chitosan composite membrane. Sensors and Actuators, B: Chemical 2013, 188, 271-279.

[56] Li, S.; Song, J.; Yang, H.; Cao, B.; Chang, H.; Deng, A. An immunochromatographic assay for rapid and direct detection of 3-amino-5-morpholino-2-oxazolidone (AMOZ) in meat and feed samples. J. Sci. Food Agric. 2014, 94, $760-767$.

[57] Xu, Z.-.; Shen, Y.-.; Beier, R.C.; Yang, J.-.; Lei, H.-.; Wang, H.; Sun, Y.-. Application of computer-assisted molecular modeling for immunoassay of low molecular weight food contaminants: A review. Anal. Chim. Acta 2009, 647, $125-136$.

[58] Wang, Q.; Liu, Y.; Chen, Y.; Jiang, W.; Shi, J.; Xiao, Y.; Zhang, M. Development of a direct competitive chemiluminescent ELISA for the detection of nitrofurantoin metabolite 1-amino-hydantoin in fish and honey. Analytical Methods 2014, 6, 4414-4420.

[59] Vass, M.; Diblikova, I.; Kok, E.; Stastny, K.; Frgalova, K.; Hruska, K.; Franek, M. In-house validation of an ELISA method for screening of semicarbazide in eggs. Food Addit. Contam. Part A Chem., Anal., Control, Expo. Risk Assess. 2008, 25, 930-936. 
[60] Yin, Y.; Liu, L.; Song, S.; Kuang, H.; Xu, C. Development of a highly sensitive icELISA to detect semicarbazide based on a monoclonal antibody. Food Agric. Immunol. 2015, 26, 356-365.

[61] Turner, A.P.F.; Karube, I.; Wilson, G.S. Biosensors: Fundamentals and Applications; Oxford University Press: Oxford, 1987.

[62] O'Mahony, J.; Moloney, M.; McConnell, R.I.; Benchikh, E.O.; Lowry, P.; Furey, A.; Danaher, M. Simultaneous detection of four nitrofuran metabolites in honey using a multiplexing biochip screening assay. Biosens. Bioelectron. 2011, 26, 4076-4081.

[63] Liu, Y.; Jiang, W.; Chen, Y.; Zeng, P.; Zhang, M.; Wang, Q. Simultaneous detection of four nitrofuran metabolites in honey using high-throughput suspension array technology. Analytical Methods 2015, 7, 4097-4103.

[64] McNamee S.E.; Rosar G.; Elliott C.T.; Campbell K. A novel multispot ELISA for antibiotic screening In: Proceedings of the Euroresidue VII Conference, Egmond aan Zee, The Netherlands, May 23-25, 2016; 2016, P132, page 657.

[65] Jester, E.L.E.; Abraham, A.; Wang, Y.; El Said, K.R.; Plakas, S.M. Performance evaluation of commercial ELISA kits for screening of furazolidone and furaltadone residues in fish. Food Chem. 2014, 145, 593-598.

[66] Krongpong, L.; Futami, K.; Katagiri, T.; Endo, M.; Maita, M. Application of ELISA-based kit for detecting AOZ and determining its clearance in eel tissues. Fisheries Science 2008, 74, 1055-1061.

[67] Tsai, C.; Hsu, C.; Wang, W. Determination of Nitrofuran Residues in Tilapia Tissue by Enzyme-Linked Immunosorbent Assay and Confirmation by Liquid Chromatography Tandem Mass Spectrometric Detection. J. Chin. Chem. Soc. 2009, 56, 581-588.

[68] Dimitrieska-Stojkovic, E.; Arsova, G.; Hajrulai-Musliu, Z.; Stojanovska-Dimzoska, B.; Uzunov, R.; Todorovic, A.; Stojkovic, G. In-house validation and quality control of commercial enzyme-linked immunosorbnet assays for screening of nitrofuran metabolites in food of animal origin. Macedonian Veterinary Review, 2012, 35, 13-21.

[69] Yibar, A.; Cetinkaya, F.; Soyutemiz, G.E. Nitrofuran Metabolite 3-amino-2-oxazolidinone Residues in Chicken Liver: A Screening Study. Asian Journal of Animal and Veterinary Advances 2012, 7, 346-350.

[70] Shen, J.; Wang, W.; Xia, X.; Zhu, J.; Wu, X.; Wang, S.; Niu, L.; Ding, S.; Wang, Z.; Wang, Z.; Li, X.; Jiang, H. Determination of Four Nitrofuran Metabolites and Chloramphenicolin Biological Samples Using Enzyme-Linked Immunosorbent Assay. Anal. Lett. 2013, 46, 1404-1418.

[71] Oliveri Conti, G.; Copat, C.; Wang, Z.; D'Agati, P.; Cristaldi, A.; Ferrante, M. Determination of illegal antimicrobials in aquaculture feed and fish: An ELISA study. Food Control 2015, 50, 937-941. 
Parent nitrofuran<smiles>O=C1OCCN1/N=C/c1ccc([N+](=O)[O-])o1</smiles>

Furazolidone<smiles>O=C1OC(CN2CCOCC2)CN1/N=C/c1ccc([N+](=O)[O-])o1</smiles>

Furaltadone<smiles>CCOCCO</smiles><smiles>NC(=O)N=Nc1ccc([N+](=O)[O-])o1</smiles>

Nitrofurazone<smiles>O=C(N/N=C/c1ccc([N+](=O)[O-])o1)c1cc([N+](=O)[O-])cc([N+](=O)[O-])c1O</smiles>

Nifursol
Corresponding nitrofuran metabolite<smiles>[R]OC1COC(=O)N1N</smiles><smiles>CC(C)=O</smiles><smiles>NN1CC(=O)NC1=O</smiles><smiles>NNC(N)=O</smiles><smiles>NNC(=O)c1cc([N+](=O)[O-])cc([N+](=O)[O-])c1O</smiles>

DNSH

Figure 1. Chemical structures of the major nitrofurans and their corresponding metabolites 
<smiles>NN1CCOC1=O</smiles>

$\mathrm{AOZ}$<smiles>O=Cc1cccc(C(=O)O)c1</smiles>

3-Carboxybenzaldehyde (3-CBA)<smiles></smiles>

3-Carboxyphenyl AOZ (3-CPAOZ)

Figure 2. The derivatisation of AOZ using 3-Carboxybenzaldehyde (3-CBA) to leave the hapten with a carboxylic acid functional group available for protein conjugation<smiles>O=C1OCCN1/N=C/c1ccccc1[N+](=O)[O-]</smiles>

2-Nitrophenyl AOZ (2-NPAOZ)

Figure 3. AOZ in samples is often converted to NPAOZ to allow interaction with antibodies raised against $\mathrm{CPAOZ}$<smiles>NN1CCOC1=O</smiles>

$\mathrm{AOZ}$<smiles>O=Cc1ccc(C(=O)O)cc1</smiles>

4-Carboxybenzaldehyde (4-CBA)<smiles>O=C(O)c1ccc(C=NN2CCOC2=O)cc1</smiles>

4-Carboxyphenyl AOZ (4-CPAOZ)

Figure 4. An alternative derivatising agent, 4-Carboxybenzaldehyde (4-CBA), was used to create an AOZ hapten that could couple to a protein with potentially less steric hindrance of the epitope than 3-CBA<smiles>NN1CCOC1=O</smiles>

$\mathrm{AOZ}$<smiles>O=C1C=CC(=O)O1</smiles><smiles>C[12CH2]</smiles>

Maleic anhydride<smiles>O=C(O)/C=C/C(=O)NN1CCOC1=O</smiles>

Figure 5. Maleic anhydride was used to convert $\mathrm{AOZ}$ to a reactive hapten 
<smiles>O=C(O)COc1ccc([N+](=O)[O-])c(C=NN2CCOC2=O)c1</smiles>

2-NP-HXA-AOZ

Figure 6. A nitrophenyl-hexanoic acid derivative of $\mathrm{AOZ}$ used as an immunogen hapten<smiles>O=Cc1cccc(OCC(=O)O)c1</smiles>

3-Formylphenoxy acetic acid (3-FPA)<smiles>O=Cc1ccc(OCC(=O)O)cc1</smiles>

4-Formylphenoxy acetic acid (4-FPA)

Figure 7. Two analogues of formylphenoxy acetic acid were used as alternatives to the carboxybenzaldehyde derivatising agents and provided two additional atoms to the length of the associated haptens<smiles>NNC(=O)c1cc([N+](=O)[O-])cc([N+](=O)[O-])c1O</smiles>

DNSH<smiles>O=CC(=O)O</smiles>

Glyoxylic acid<smiles>O=C(O)/C=N/NC(=O)c1cc([N+](=O)[O-])cc([N+](=O)[O-])c1O</smiles>

DNSH glyoxylate

Figure 8. DNSH was derivatised with glyoxylic acid to create a DNSH glyoxylate hapten 
<smiles>O=Cc1ccc([N+](=O)[O-])o1</smiles>

5-Nitrofurfural (NFF)
$+\left[\mathrm{H}_{2} \mathrm{~N}=\mathrm{NH}_{2}\right] \mathrm{SO}_{4}$

Diamine sulphate<smiles>NN=Cc1ccc([N+](=O)[O-])o1</smiles>

Generic hapten

Figure 9. 5-Nitrofurfural reacted with diamine sulphate to produce a generic nitrofuran hapten with a reactive amine for protein conjugation

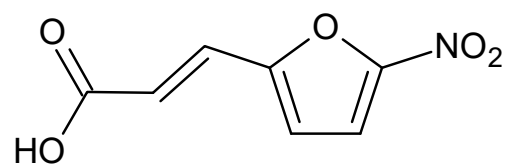

3-(5-nitro-2-furyl) acrylic acid

Figure 10. 3-(5-nitro-2-furyl) acrylic acid was selected as a generic nitrofuran hapten possessing a reactive carboxylic acid for protein conjugation 